\title{
Reshaping R\&D Tax Incentive Policy in Terms of International Tax Competition
}

\section{A K+F adóügyi ösztönző politika újragondolása a nemzetközi adóverseny vonatkozásában}

Policies to stimulate research and development are high on the government's agenda and affect businesses growing internationally. The article highlights the role of tax incentives in the policy mix to promote private research and development (R\&D). It discusses evolution and recent trends in $R \& D$ tax incentive schemes in European countries. The impact of international tax competition on their adoption and generosity is investigated. Moreover, a decision-making model on implementation and generosity of $R \& D$ tax incentives is introduced.

JEL classification: $\mathrm{H} 25, \mathrm{H} 26, \mathrm{H} 32$

Keywords: R\&D tax incentives; tax relief; tax support; generosity of tax incentives; tax competition

A kutatás-fejlesztést stimuláló politika fontos célkitüzés a kormányzat részérôl, amely érinti a nemzetközi színtéren növekvő vállalatokat is. A tanulmány az adóügyi ösztönzők szerepére világít rá a magánberuházói kutatás-fejlesztést (K+F) támogató politikai eszközök között. Tárgyalja a K+F adóügyi ösztönzők kialakulását, fejlődését és legújabb trendjeit az európai országok vonatkozásában. A nemzetközi adóverseny hatása ezek bevezetésére szintén vizsgálat tárgyát képezi. Továbbá egy, a K+F adóügyi ösztönzők bevezetésével és az alkalmazásuk széleskörüségével kapcsolatos döntéshozatali modell is ismertetésre kerül.

JEL-klasszifikáció: H25, H26, H32

Kulcsszavak: $\mathrm{K}+\mathrm{F}$ adóösztönzők; adókedvezmények; adótámogatás; adóügyi ösztönzők széleskörűsége; adóverseny

Katsiaryna Marmilava is a $\mathrm{PhD}$ candidate at the Institute of Finance and Accounting, University of Miskolc. E-mail: marmilava@gmail.com 


\section{Introduction}

Research and development (R\&D) tax incentives have become an increasingly important instrument in the policy mix to stimulate private R\&D in many countries around the world. Over the past several decades the number of OECD countries promoting R\&D tax incentive schemes has increased from twelve in 1996, to nineteen in 2006, to thirty in 2018. ${ }^{1}$ Moreover, most countries have made the many changes to tax incentive schemes to increase their generosity and attractiveness. Along with the persistent or growing direct government funding of R\&D in most OECD countries, the total government support of R\&D has increased significantly.

From the classical point of view, underinvestment in $R \& D$ is justified due to the high risks associated with $R \& D$ activity and decreased innovator's benefits due to knowledge spillovers. However, currently this is no longer the sole justification for the public support of private R\&D. Most countries have been adopting goals-based policies considering R\&D as a key driver of productivity and economic growth. The Europe 2020 strategy emphasises the impact of R\&D on long-term growth and employment and sets the aim of increasing combined public and private investment in $R \& D$ to 3 per cent of GDP by $2020 .^{2}$ In support of this strategy, all EU Member States set individual goals for the desired level of business $R \& D$ that can be achieved by raising either domestic or external R\&D investment. Given the mobile nature of R\&D investment and intellectual property (IP), governments strive to provide more beneficial tax treatment, engaging in international tax competition and adapting their R\&D tax incentive policies to general trends.

\section{Public support of business R\&D: direct funding versus indirect support measures}

Governments can choose between two main ways to support private R\&D spending: direct financing (such as grants, subsidies and the like) or tax stimuli for R\&D, or a combination of the two. Direct financing helps to support strategic goals of state R\&D policy by providing support for a limited number of carefully reviewed R\&D projects; however, it leaves the market little freedom to choose which research and development should be conducted and how. If a country's project selection process is not clear enough and is rooted in political interests, it can discourage firms from even undertaking R\&D projects, especially those with high risk or a low private rate of return. In such a climate, tax incentives are more neutral (and hence favourable) to $R \& D$ performers as they encourage

OECD Review of National R\&D Tax Incentives and Estimates of R\&D Tax Subsidy Rates. TAX4INNO Project 674888, Deliverable 3.5: Summary report on tax subsidy rates - core countries (Year 3), Version 26 February 2019. OECD, Paris.

2 EUROPE 2020. A strategy for smart, sustainable and inclusive growth. Communication from the Commission Brussels. 3.3.2010 COM (2010), European Commission, Brussels, 2020. 
firms to take more initiative based on their own market insights. Moreover, in today's globalised competition and fast-changing technology environment, firms might be better allocators of resources as they can react more quickly to technological and market changes. ${ }^{3}$

In the early 2000s direct financing of R\&D was the main measure of government support of business $R \& D$, while indirect government support through tax incentives was provided in only nine European countries (Figure 1).

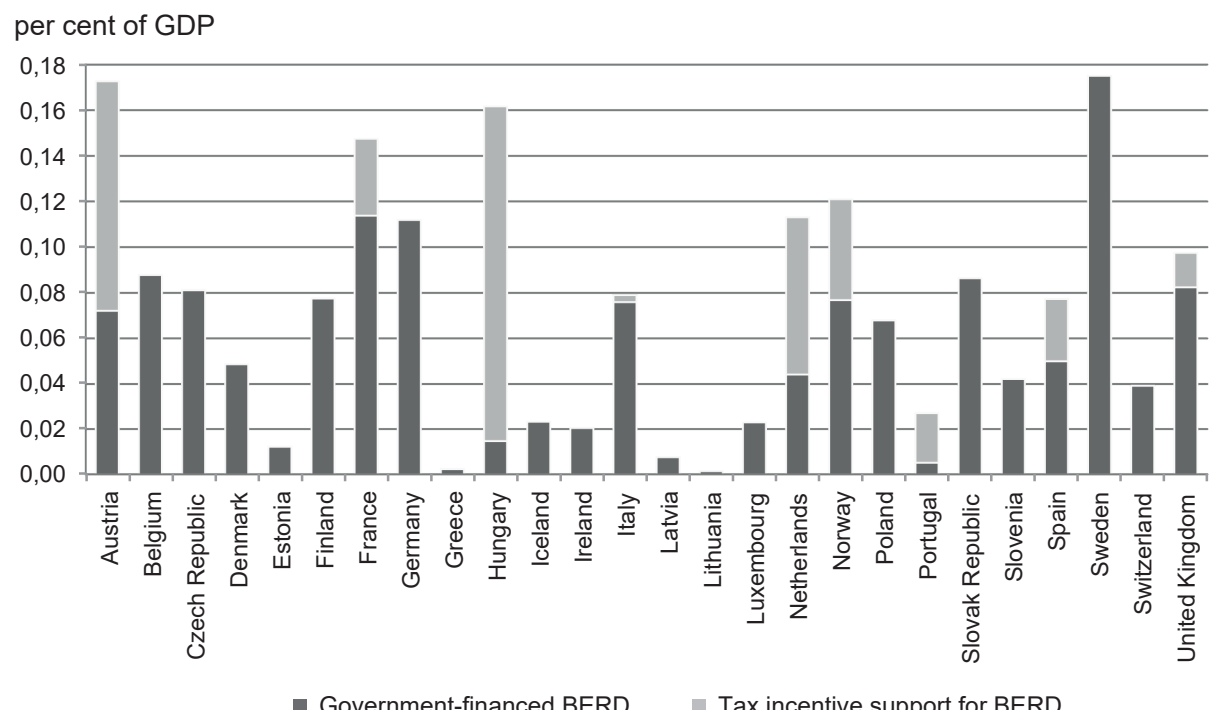

Figure 1

Direct government funding and tax support for business R\&D in European countries, 2001 Note: Figures for Austria are for 2002, for Hungary 2004, for tax incentive support in Norway 2002, for Luxembourg and Switzerland 2000, for Spain 2002

Source: edited by the author based on the OECD Database - R\&D Tax Incentive Indicators, June 2020.

The highest amount of tax support for business enterprise $R \& D$ expenditure (BERD) as a percentage of GDP was provided in Hungary, Austria, and the Netherlands, which prevailed over direct financing in those countries, followed by Norway, France, Spain, Portugal, the United Kingdom and Italy with less significant R\&D tax support. At the same time the coverage of BERD by tax incentives differed significantly: while in Hungary 41.6 per cent of BERD was financed through tax incentives (due to the low level of BERD - 0.35 per cent of GDP), in Austria the share of supported business R\&D expenditure was 7.3 per cent (which corresponded to 1.38 per cent of BERD of GDP), and 7.1 per cent in the Netherlands (with 0.98 per cent of BERD of GDP). ${ }^{4}$

Adão Carvalho, 'Why are tax incentives increasingly used to promote private R\&D?' CEFAGE-UE Working Papers, University of Evora, CEFAGE-UE, Portugal, April 2011.

According to 'Main Science and Technology Indicators', The OECD MSTI database, June 2020.

Európai Tükör 2020/4. 
In the following years, the internationalisation of the markets and the strategic focus of many OECD countries on R\&D as a key factor of competitiveness and economic growth brought new light on R\&D tax incentive policies. While direct financing can be applied to a limited number of applicants, ${ }^{5}$ tax incentives are more suited in principle to encourage $R \& D$ activities oriented towards the development of applications that have the potential to be brought to the market within a reasonable timeframe. ${ }^{6}$ Therefore $R \& D$ tax incentives can be a better means of attracting the R\&D activities of multinational corporations which typically account for a substantial share of R\&D expenditure. Besides, compared with direct subsidies, tax incentives tend to be more compliant with competition and international trade rules. ${ }^{7}$ Exemptions from international agreements (for example in the European Union, the World Trade Organization) made tax support for $R \& D$ one of the few ways that governments could help domestic firms improve competitiveness without direct state aid.

From 2001 to 2017 the distribution of direct and indirect (tax incentive) support for private R\&D has been changing among European countries. Many of them have introduced $R \& D$ tax incentive schemes that align with direct government measures, resulting in an increase in total government support provided. The most significant growth of total government support for R\&D in GDP was in Belgium (0.28 percentage points), France (0.25 pp), the United Kingdom (0.20 pp), Iceland (0.21 pp) and Ireland (0.17 pp). ${ }^{8}$ While in Iceland the growth was equally attributable to the increase in direct and tax support for R\&D, in Belgium, France, the United Kingdom and Ireland, it was mainly affected by R\&D tax incentive policies (Figure 2).

Direct financing over the same period decreased significantly in the Slovak Republic, from 0.09 per cent of GDP in 2001 to 0.01 per cent of GDP in 2017, and in Sweden from 0.18 per cent to 0.11 per cent of GDP. Besides, they were among the last countries to introduce R\&D tax incentives (2014 in Sweden, 2015 in the Slovak Republic ${ }^{9}$ ), providing relatively low tax support (around 0.01 per cent of GDP). In Italy the decrease in direct financing of private $R \& D$, from 0.08 per cent to 0.03 per cent of GDP, was offset by tax support which has grown since the adoption of more generous $R \& D$ tax incentive schemes from 0.05 per cent in 2015 to 0.18 per cent of GDP in 2017.

Evaluation and design of $R \& D$ tax incentives, OMC Crest Working Group report submitted to meeting in CREST $17^{\text {th }}$ March 2006.

$6 \quad R \& D$ tax incentives: design and evidence, Working Party on Innovation and Technology Policy Document, DSTI/IND/STP, OECD, Paris, June 14, 2016.

$7 \quad$ Silvia Appelt, Matej Bajgar, Chiara Criscuolo, and Fernando Galindo-Rueda: R\&D Tax Incentives: Evidence on design, incidence and impacts, OECD Science, Technology and Industry Policy Papers No. 32, 2016.

8 In 2014 the total amount of tax support in Ireland reached its maximum - 0.35 per cent of GDP increasing from 2001 by 0.33 percentage points ( 0.28 pp of which was attributable to $R \& D$ tax incentives). However, the following decrease of total government support in GDP was partly affected by the overestimated size of the economy as a result of tax avoidance strategies pursued by multinational companies. Until 2015, an R\&D tax allowance in the Slovak Republic was only available to grant recipients. 


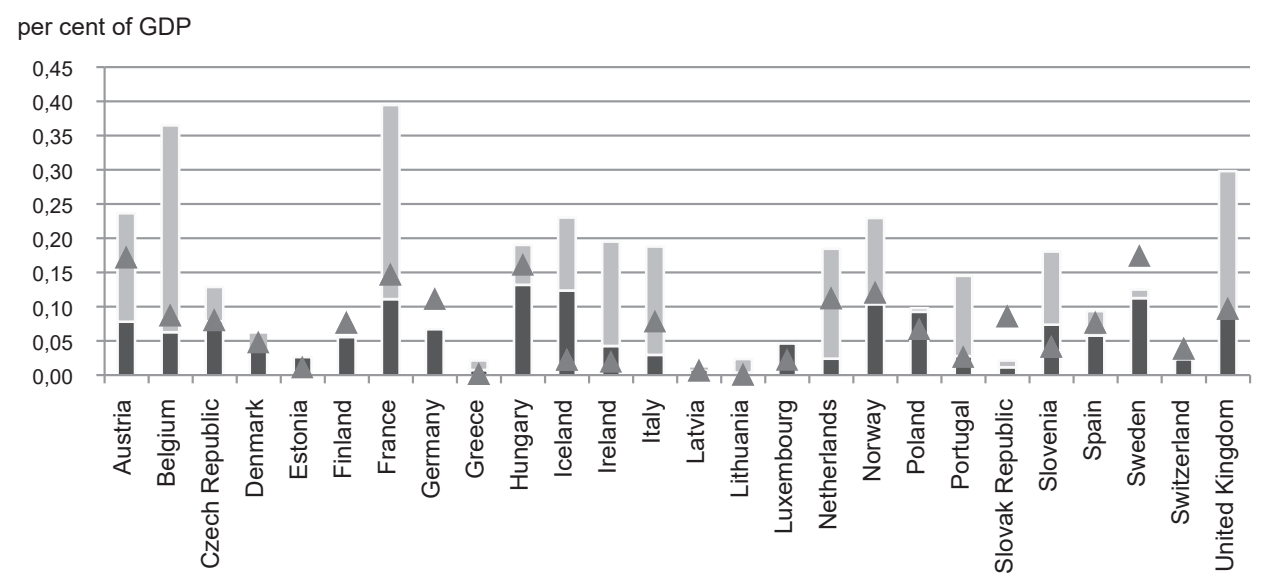

n Government-financed BERD $\quad$ Tax incentive support for BERD $\quad \Delta$ Total government support for BERD, 2001

Figure 2

Direct government funding and tax support for business R\&D in European countries, 2017

Note: Figures for Greece are for 2016.

Source: edited by the author based on the OECD Database - R\&D Tax Incentive Indicators,

September 2020.

In contrast, direct support of R\&D in Hungary over the period 2004-2017 increased from 0.01 per cent to 0.13 per cent of GDP (with a temporary drop in 2016), while tax support of R\&D dropped from 0.15 per cent to 0.06 per cent of GDP, mainly due to reductions in corporate tax and social security contribution rates, which decreased the significance of tax incentives. ${ }^{10}$

Some countries (Germany [up to 2020], Switzerland, Finland ${ }^{11}$ ) do not offer R\&D tax incentives or have adopted a limited amount of them (for example, Denmark); however, they have a relatively high level of business investment in $R \& D$ due to overall high competitiveness of national economies (2.03 per cent, 2.26 per cent, 1.59 per cent and 1.78 per cent of GDP, for the afore-mentioned countries, respectively, with the EU average at 1.14 per cent of GDP in 2017). ${ }^{12}$ At the same time, the proportion of business enterprise R\&D expenditure financed by business sector from abroad constituted only 6 per cent in Germany in 2015, and only 4 per cent in Denmark (having decreased from 11 per cent in 2003), while in some countries which adopted $R \& D$ tax incentive schemes the percentage was higher (for example, 19 per cent in Austria, 14 per cent in Belgium and in Hungary, 16 per cent in the United Kingdom, 12 per cent in Norway, and 10 per cent in the Netherlands). ${ }^{13}$ Therefore, government support of R\&D, particularly through $R \& D$ tax incentives, may play a role in the internationalisation of $R \& D$ investment.

\footnotetext{
10 In Hungary the value of R\&D tax deductions is directly linked to the corporate income tax rate (R\&D tax allowance) and social contribution rate (SSC exemption).

11 The R\&D tax incentive scheme introduced by Finland in 2013-2014 was only temporary.

12 According to the 'Main Science and Technology Indicators', June 2020.

13 According to Eurostat' statistics - Science, Technology and Digital Society Database, February 2021.
} 


\section{Designing generosity of R\&D tax incentive schemes}

When adopting $R \& D$ tax incentive schemes the government has to determine its generosity. In terms of international competition for $R \& D$ capital tax incentives should be aimed not only at reinforcing the internal R\&D base, but also at making the country more attractive to external R\&D investment. The key indicator which allows cross-country comparisons of the generosity of R\&D tax incentives, known as the B-index, was developed by Warda and McFetridge, ${ }^{14}$ and is widely used with some extensions by OECD countries today to monitor changes in the level of attractiveness of $R \& D$ tax treatment. The B-index is calculated as the present value of before-tax income that a firm needs to generate in order to cover the cost of an initial R\&D investment and to pay the applicable income taxes. ${ }^{15}$ The notional tax subsidy rate, calculated as 1 minus the B-index, shows how many monetary units of government tax support are provided for an additional monetary unit of R\&D outlay.

Determining the potential generosity of $R \& D$ tax incentives is important while implementing R\&D tax incentives or introducing changes in tax treatment for R\&D in order to predict possible outcomes of the policy. The decision-making process involved in adopting $R \& D$ tax incentive schemes and determining its generosity can be described with a model (Figure 3). The model can be applied by countries which prioritise innovation development of the economy and recognise the importance of tax assistance in achieving R\&D state targets.

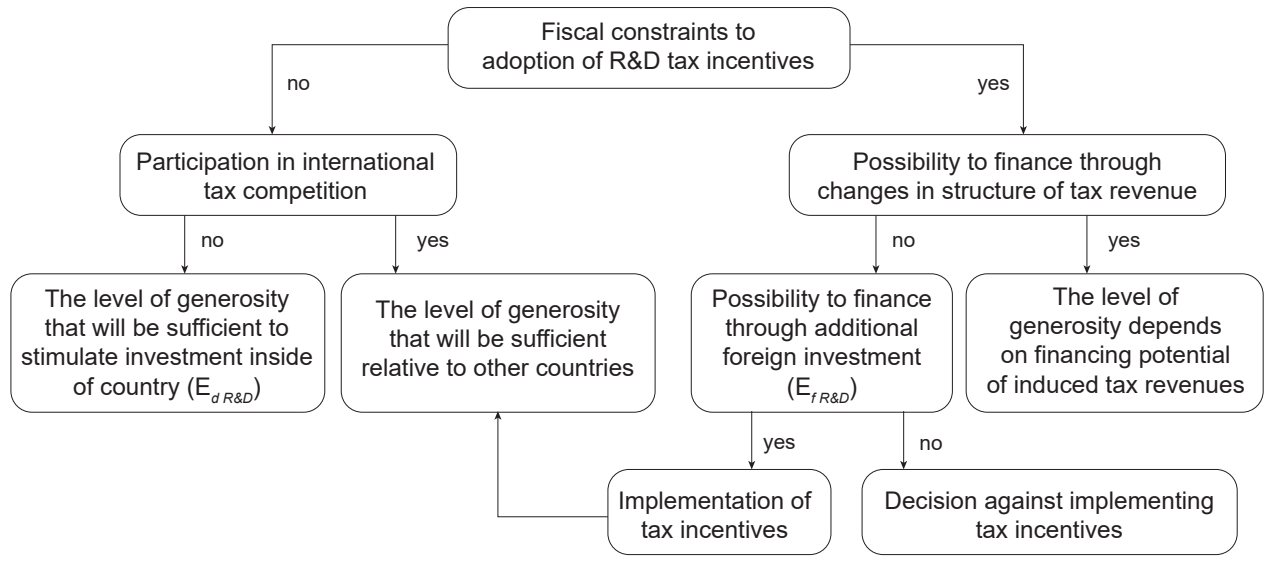

Figure 3

Decision making model on implementation and generosity of $R \& D$ tax incentives

Note: $E_{d R \& D}$ and $E_{f R \& D}$ indicate elasticities of domestic and foreign business investment, respectively, to $R \& D$ tax incentives.

Source: edited by the author

14 Donald G McFetridge and Jacek P Warda: Canadian R\&D Tax Incentives: Their Adequacy and Impact (Toronto: Canadian Tax Foundation, 1983).

15 Jacek P Warda, 'Measuring the value of R\&D Tax Treatment in OECD Countries', STI Review: Special Issue on New Science and Technology Indicators, OECD Publishing 27 (2001), 185-211. 
The key points in the decision-making process are the existence of fiscal constraints to the adoption of R\&D tax incentives and the country's openness to international investment. A country which has disciplined public finances has more flexibility when designing tax incentive schemes. However, in the presence of fiscal constraints, a government should consider possibilities to finance future tax relief. It may decide to increase tax revenues through changes in its structure (for example, by increasing tax rates, broadening the tax base or removing unjustified tax expenditures), or it may introduce R\&D tax incentives, expecting that they will attract additional investment primarily from the foreign business sector that will contribute to tax revenues of the domestic economy. In this case, the elasticity of foreign R\&D investment to tax parameters is important.

Thus, after joining the European Union in 2004 the Czech Republic and Slovenia introduced $R \& D$ tax incentives in 2005, expecting that with lowered entry barriers to foreign direct investment these tax benefits may attract additional foreign investment in R\&D. At the same time, the existing Member States responded to increased competition from the new entries by similarly adopting R\&D tax incentives, or increasing the generosity of existing R\&D tax incentives. Thus, for example, Ireland launched its R\&D tax incentive scheme from 2004, Belgium and Italy offered additional R\&D tax incentives in 2005 and 2007 respectively, while France increased the generosity of existing R\&D tax incentives in 2004 by incorporating a volume-based element in its incremental scheme (the tax incentive could be applied additionally to the absolute amount of R\&D rather than to the increment only).

While designing R\&D tax support measures it should be taken into account that the distribution of foreign R\&D investment and foreign direct investment varies; moreover, generous tax incentives do not always lead to additional R\&D investment. For example, Spain and Portugal offer generous tax incentive schemes for R\&D; however, BERD financed by business sector from abroad constituted only 0.03 per cent of GDP in Spain, and only 0.01 per cent of GDP in Portugal in 2017, which is significantly lower than in other European countries providing tax support for BERD (for example, 0.12 per cent in Slovenia, 0.16 per cent in the Netherlands, 0.34 per cent in the Czech Republic, 0.42 per cent in Austria, and 0.14 per cent in Hungary and the United Kingdom). At the same time, foreign direct inflows in Portugal and Spain were at 3 per cent of GDP in 2017, which is slightly higher than the European Union (28) average (2.4 per cent of GDP). The reason behind the low elasticity of foreign $R \& D$ investment to tax parameters in these countries can be hidden in the fact that their economies are for the large part specialised in activities of low or medium-low technological intensity. Therefore, attracting foreign $\mathrm{R} \& \mathrm{D}$ investment by means of tax incentives can prove more difficult.

Some countries have provided an evaluation of their R\&D tax incentives in order to assess whether the $R \& D$ tax relief is internationally competitive. A review of the Ministry of Finance of Ireland as a part of Budget 2013 revealed that the R\&D tax benefit scheme appeared to be an important aspect in tax competition over R\&D location decisions and played an important role in attracting foreign direct investment to Ireland. ${ }^{16}$

$16 \quad$ A Study on R\&D Tax Incentives. Annex: Good practice cases. Final report, TAXUD/2013/DE/315. FWC No. TAXUD/2010/CC/104. CPB Netherlands Bureau for Economic Policy Analysis (Consortium leader), European Commission. The Hague, the Netherlands, November 28, 2014.

Európai Tükör 2020/4. 
If a country relies on tax incentives to spur growth predominantly in domestic R\&D investment, it will likely have to factor in a certain time lag before it sees the growth in productivity and tax revenues that those incentives are expected to engender. In such a case, the budget deficit brought about by the R\&D tax incentives can be financed through changes in the structure of tax revenues. Historical evidence suggests that during the 2008 global financial crisis, when many European countries had growing budget deficits, Belgium, France, Ireland, the Netherlands, Portugal, Slovenia, and the United Kingdom were among those countries that increased the generosity of their R\&D tax incentives, while Lithuania began offering generous $R \& D$ tax incentives in 2008 to support private investment (Figure 4). At the same time, various measures were implemented in those countries to offset the negative impact of the tax stimulus on their national budgets. For example, Portugal and the United Kingdom raised their personal income tax rates, whereas Ireland and the Netherlands increased their Social Security Contribution rates. While Lithuania and Ireland chose to up their VAT rates, France levied new taxes on financial transactions.

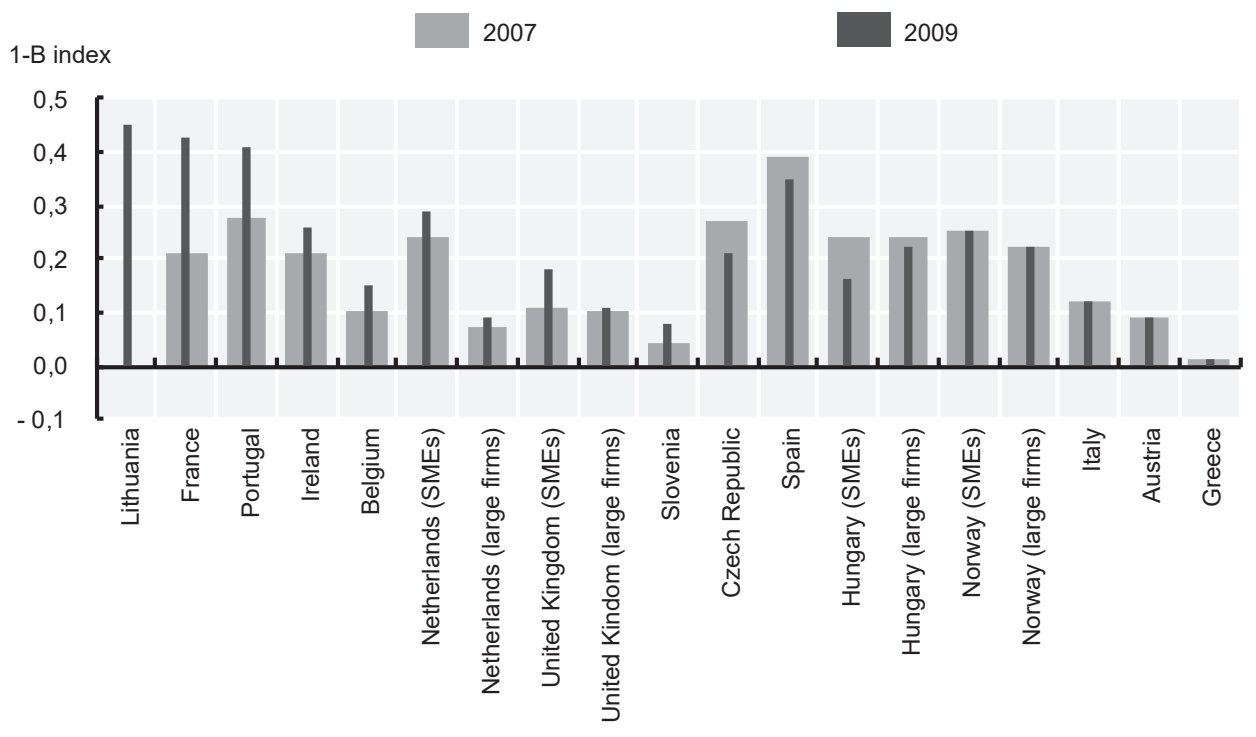

Figure 4

Generosity of $R \& D$ tax incentives before and during the global financial crisis

Note: Hungary, the Netherlands, the United Kingdom, and Norway differentiate implied tax subsidy rates depending on the firm's size. Figures for Hungary and Slovenia refer to 2010 instead of 2009, when the changes to $R \& D$ tax incentive schemes were introduced. Source: edited by the author based on OECD statistics, R\&D Tax Incentive Indicators, June 2020.

The Czech Republic, Spain and Hungary, who had been offering generous tax incentives in 2007 going into the financial crisis, decided they had to limit their generosity in order to maintain fiscal stability. Taking the opposite approach, Austria, Greece and Italy, which had been relatively stingy with their R\&D tax incentives, kept an even keel during 
the crises, while Norway, which had a significant budget surplus, was in the enviable position of being able to continue supporting private $R \& D$ investment through generous tax incentives.

A country's openness to foreign investment plays an important role in shaping R\&D tax incentive policy. ${ }^{17}$ Some countries have a lower degree of openness due to different sort of barriers (for example, investment and trade barriers, restrictions on the labor market, and so on). As such, they should structure their tax incentives in such a way as making them attractive primarily for domestic R\&D investors, therefore avoiding losses from unwarranted R\&D tax giveaways. In fact the evidence suggests that countries with lesser trade openness, such as Italy and Turkey, have lower foreign direct investment stocks relative to GDP, and less generous R\&D tax incentives. ${ }^{18}$ The tax subsidy rate for profit-making enterprises in 2017 was 0.09 in Italy and 0.06 in Turkey, ${ }^{19}$ while the OECD median was estimated at 0.19 for SMEs and 0.11 for large enterprises. ${ }^{20}$

As non-tax barriers decline, investment decisions and location of investment become more tax sensitive. ${ }^{21}$ If a country has a favorable investment environment and may benefit from additional foreign investment, the generosity of R\&D tax incentives is to be determined on a competitive basis. Since tax incentives can affect location choices for $R \& D$ investment especially between countries that are similar in other respects, a country while set out to design tax support should refer to the one provided by keen rivals. As an example, Portugal first introduced its R\&D tax incentive scheme (SIFIDE) in 1997 using the Spanish tax incentive scheme as a reference to remain attractive for R\&D investment, particularly in relation to its neighbour Spain. Among the reasons for the changes to SIFIDE in 2001 was the change made to the Spanish tax incentive scheme, and that "the Portuguese tax incentive scheme must remain competitive to similar systems". ${ }^{22}$

In many countries, overall tax relief for business research and development may be greater than governments originally intended when they designed tax support of business $R \& D$ expenditures. This may be compounded by the rising generosity of tax incentives for $\mathrm{R} \& \mathrm{D}$ observed in recent years, the full cost of which is not always transparent because R\&D tax incentives are 'off budget' as a tax expenditure. ${ }^{23}$ To maintain control over the budget allocated to tax incentives, most governments put a ceiling on the absolute amount of R\&D that can be claimed, or on the maximum amount of the tax incentive that can be deducted. Some countries require pre-approval of R\&D projects for which tax incentives can be claimed and introduce budgetary limits by rationing the

\footnotetext{
17 Openness here is being understood as the degree to which non-domestic actors participate in a domestic economy.

18 According to 'World Indicators of Skills for Employment (WISE) Dataset', The OECD R\&D Statistics database, June 2020.

19 Turkey and Italy do not differentiate tax support depending on the enterprise's size.

20 According to 'World Indicators of Skills for Employment (WISE) Dataset', June 2020.

21 Luigi Bernardi and Laura Fumagalli and Luca Candullia, 'Overview of the tax systems and main tax policy issues', in Tax systems and Tax reforms in South and East Asia (London: Routledge, 2006).

22 Adão Carvalho and Beatriz Corchuelo, 'Business R\&D Policy in Spain and Portugal: Objectives, Incentives and Outcomes', Anales de Economía Aplicada, La Economía en la Sociedad del (Des) Conocimiento, July 2013, 689.

23 The Innovation Imperative: Contributing to Productivity, Growth and Well-Being, OECD, October 14, 2015.
} 
number of approved claims. In these cases $R \& D$ tax incentives take on features of direct subsidies, which can decrease their attractiveness.

\section{Evolution and recent trends in $R \& D$ tax incentive schemes}

The evolution of R\&D tax incentive schemes has been affected to a large extent by international expansion of multinational companies and increasing internationalisation of R\&D. In 2015, foreign affiliates were responsible for more than 60 per cent of R\&D expenditure of enterprises in Hungary, Ireland, the Czech Republic, Belgium, and about half of business-enterprise R\&D in Austria and the United Kingdom. ${ }^{24}$

Since R\&D activity and related income are especially sensitive to corporate taxes, ${ }^{25}$ many multinational companies looking to maximise their post-tax returns get involved in profit-shifting activities. A large body of studies has investigated the influence of tax regimes on the location of a firm's capital and profits. Harry Grubert, using data on the United States parent corporations and their manufacturing subsidiaries, found that income attributable to parent $R \& D$ accounts for around half of the income that was shifted from high-tax to low-tax countries. ${ }^{26}$ The study of Nicholas Bloom, Griffith and Van Reenen for a panel of European countries suggests that within a multinational group, $R \& D$ activities are sensitive to the user-cost of $R \& D^{27}$ at foreign affiliates, shifting to places with a lower user-cost. ${ }^{28} \mathrm{~A}$ similar conclusion was reached in a study examining location decisions across the United States. ${ }^{29}$ Moreover, the location of the patent applications is also responsive to corporate taxation. ${ }^{30}$

Over the past decade a growing number of countries have introduced income-based $\mathrm{R} \& \mathrm{D}$ tax incentives known as a patent box. A patent box is a tax incentive that offers a reduced corporate tax rate for income derived from commercial exploitation of qualified IP. Besides encouraging domestic investment in innovation, patent boxes are aimed

24 According to 'Main Science and Technology Indicators', June 2020.

25 Mihir A Desai, Fritz C Foley, and James Hines Jr, 'The Demand for Tax Haven Operations', Journal of Public Economics 90, no 3 (2006), 513-531; Sven Stöwhase, 'Profit shifting opportunities, multinationals, and the determinants of FDI', Discussion Paper No. 2002-11, Ludwig-Maximilians Universität München, Munich, December 2, 2002; Harry Grubert and Joel Slemrod, 'The effect of Taxes on Investment and Income Shifting to Puerto Rico', Review of Economics and Statistics 80, no 3 (1998), 365-373. Harry Grubert, 'Intangible Income, Intercompany Transactions, Income Shifting, and the Choice of Location', National Tax Journal 56, no 1 (2003), 221-242.

27 A summary measure of the tax-inclusive cost of R\&D.

28 Nicholas Bloom, Rachel Griffith, and John Van Reenen, 'Do R\&D Tax Credits Work? Evidence from a panel of countries 1979-1997', Journal of Public Economics 85, no 1 (2002), 1-31. Tredits', The Review of Economics and Statistics 91, no 2 (2009), 431-436.

$30 \quad$ Supporting Investment in Knowledge Capital, Growth and Innovation, OECD, 2013; Tom Karkinsky and Nadine Riedel, 'Corporate taxation and the choice of patent location within multinational firms', Journal of International Economics 88, no 1 (2012), 176-185; Rachel Griffith,Helen Miller, and Martin O'Connell, 'Ownership of Intellectual Property and Corporate Taxation', Journal of Public Economics 112 (2014), 12-23. 
at increasing tax revenues by luring IP income from abroad. Since patent boxes could be used by firms regardless of the country where the invention originated, a number of multinational companies have sought to take advantage of tax incentives by applying for patents from countries offering the patent box. In 2007, patent boxes had been introduced in only five European countries (France, Hungary, Belgium, the Netherlands, and Ireland), but by 2015 the number of European countries offering this tax incentive scheme had increased to fourteen. ${ }^{31}$ The rationale behind the scheme in some countries was the prevention of shifting domestic tax bases to lower-tax jurisdictions. Recent evidence suggests that a patent box has not affected invention itself, however; it has had an impact on patent transfers. The impact was substantially reduced in countries which adopted patent boxes with substantial development requirement for patented invention. ${ }^{32}$

In 2015, OECD countries agreed on the Modified Nexus Approach for IP regimes as part of Action 5 of the OECD's Base Erosion and Profit Shifting (BEPS) Action Plan. ${ }^{33}$ A key recommendation of the approach was for each country to limit the amount of IP income that can benefit from a patent box to the extent that the income is connected to the company's 'qualifying expenditures' in the host country. These expenditures had to be made by the company claiming the patent-box tax benefit, had to be directly connected to the qualified IP asset, and had to be similar to the expenditures that typically qualify for research tax incentives. Starting in July 2016, all patent boxes offered by OECD countries are to be based on the modified nexus approach, but pre-existing boxes may remain in effect through $2021 .{ }^{34}$ Therefore, R\&D tax incentive policy was coordinated in order to avoid pernicious effects of tax competition.

Most countries have done the many changes to expenditure-based tax incentive schemes in order to increase the availability, simplicity of use and generosity of R\&D tax incentives. Thus, for example, some countries replaced their incremental and hybrid volume-based schemes with a simpler and more generous purely volume-based scheme (for instance, France in 2008, Ireland in 2015). As of 2019, Italy was the only European country with only an incremental scheme - the tax benefit was applied only to an incremental part of R\&D expenditure. However, it was replaced by a volume-based scheme in 2020. Currently, only a few countries (the Czech Republic, the Slovak Republic, Portugal, and Spain) combine both schemes.

Many countries have extended their R\&D tax incentives to loss-making (or low profit) firms through carry-forward and refund provisions. Thus, the number of European countries offering carry-over provisions has increased from eleven in 2013 to eighteen in 2020, while cash refunds for unused claims were recently introduced in four European countries (Italy, Poland (start-ups), Germany, and the United Kingdom (large

\footnotetext{
31 These are the United Kingdom, Spain, Portugal, Italy, Luxembourg, Greece, Malta, Cyprus, Belgium, Hungary, Ireland, France, the Netherlands, and Liechtenstein.

32 Fabian Gaeddler, Bronwyn H Hall, and Dietmar Harhoff, 'Should there be Lower Taxes on Patent Income', IFD Working Paper W18/19, Institute for fiscal studies, July 2018.

33 Action 5: Agreement on Modified Nexus Approach for IP Regimes, OECD/G20 Base Erosion and Profit Shifting Project, OECD, 2015.

34 Gary Guenther, Patent Boxes: A Primer, Congressional Research Service Report, 2017.
}

Európai Tükör 2020/4. 
firms)), raising the total number of European countries using the scheme to twelve. ${ }^{35}$ Refundability can be particularly beneficial for young, innovative firms, which often lack taxable income at the stage of investing in developing and launching their products. A potential downside of such provisions is that they can also be used by firms with the ability to shift profits to other jurisdictions. ${ }^{36}$ Currently the most generous R\&D tax incentives for loss-making firms have been introduced in the Slovak Republic, France, Iceland, Portugal, and the Netherlands (for SMEs).

To improve the availability of tax incentives, most countries have introduced electronic application and one-stop agencies where all relevant questions can be settled. Such practices not only increase the attractiveness of tax incentives but also reduce the administrative burden for government and the compliance costs for firms.

\section{Conclusion}

The importance of specific R\&D tax incentives in the policy mix to promote business R\&D has increased significantly over the past several decades. Exemptions from international agreements made tax support for R\&D one of the few ways that governments could help domestic firms improve competitiveness without direct state aid. Besides, tax incentives as a market-based instrument are often better suited to respond to the growing competition for international R\&D investment. However, the optimal balance between direct measures and tax relief provisions varies among different countries and depends on policy preference and each country's specific circumstances. Generosity is a key feature of R\&D tax incentives that affects their attractiveness. The policy decisions on generosity of tax incentives should be consistent and carefully developed, taking into account the state of the government budget, the country's openness to foreign direct investment flows, and the elasticity of foreign and domestic R\&D investment to tax parameters. The evolution of R\&D tax incentive schemes over the last decade was largely affected by the internationalisation of $R \& D$ and growing tax competition for mobile $R \& D$ and intellectual property. Most changes made to $R \& D$ tax incentive schemes have been for the purpose of making them more attractive and competitive. The growing importance of income-based schemes (patent and innovation boxes) has resulted in relocating corporate income among countries, but without any significant evidence that the tax incentives behind these shifts are actually resulting in a positive impact on the development of new intangible assets. The implementation of the BEPS action plan has resulted in countries revising their existing IP or patent boxes, while other countries have introduced new schemes that are compatible with the BEPS rules.

35 'Main features of R\&D tax incentives provisions in selected OECD and non OECD countries', OECD, 2020; OECD R\&D tax incentives database, 2020 edition, OECD, December 16, 2020.

36 ' $R \& D$ tax incentives'. 


\section{References}

Action 5: Agreement on Modified Nexus Approach for IP Regimes. OECD/G20 Base Erosion and Profit Shifting Project, OECD, Paris, 2015. Online: www.oecd.org/ctp/beps-action-5-agreement-on-modified-nexus-approach-for-ip-regimes.pdf

Appelt, Silvia - Matej Bajgar - Chiara Criscuolo - Fernando Galindo-Rueda: R\&D Tax Incentives: Evidence on design, incidence and impacts. OECD Science, Technology and Industry Policy Papers No. 32, 2016. Online: https://doi.org/10.1787/5jlr8fldqk7j-en

A Study on R\&D Tax Incentives. Annex: Good practice cases. Final report. TAXUD/2013/ DE/315. FWC No. TAXUD/2010/CC/104. CPB Netherlands Bureau for Economic Policy Analysis (Consortium leader), European Commission. The Hague, the Netherlands, November 28, 2014. Online: https://ec.europa.eu/taxation_customs/ sites/taxation/files/resources/documents/taxation/gen_info/economic_analysis/ tax_papers/good_practice_cases.pdf

Bernardi, Luigi - Laura Fumagalli - Luca Candullia: Overview of the tax systems and main tax policy issues. In Luigi Bernardi - Angela Fraschini - Parthasarathi Shome: Tax Systems and Tax Reforms in South and East Asia. London, Routledge, 2006. Online: https://doi.org/10.4324/9780203088241

Bloom, Nicholas - Rachel Griffith - John van Reenen: 'Do R\&D tax credits work? Evidence from a panel of countries 1979-1997'. Journal of Public Economics 85, no 1 (2002), 1-31. Online: https://doi.org/10.1016/s0047-2727(01)00086-x

Carvalho, Adão: 'Why are tax incentives increasingly used to promote private R\&D?' CEFAGE-UE Working Papers, University of Evora, CEFAGE-UE, Portugal, April 2011. Online: www.cefage.uevora.pt/en/content/download/2320/31134/version/ 1/file/2011_04.pdf

Carvalho, Adão - Beatriz Corchuelo: Business R\&D Policy in Spain and Portugal: Objectives, Incentives and Outcomes. Anales de Economía Aplicada 2013, Atas do XXVII Congreso Internacional de Economía Aplicada ASEPELT - La Economía en la Sociedad del (Des) Conocimiento, Zaragoza, Madrid, Delta publicaciones, ASEPELT, 4-6 de julho, 2013, 670-698.

Desai, Mihir A - C Fritz Foley - James Hines Jr.: 'The demand for tax haven operations'. Journal of Public Economics 90, no 3 (2006), 513-531. Online: https://doi. org/10.1016/j.jpubeco.2005.04.004

EUROPE 2020. A strategy for smart, sustainable and inclusive growth. Communication from the Commission Brussels. 3.3.2010 COM (2010), European Commission, Brussels, 2020. Online: https://eur-lex.europa.eu/LexUriServ/LexUriServ.do?uri=COM: 2010:2020:FIN:EN:PDF

Evaluation and design of R\&D tax incentives. OMC Crest Working Group report submitted to meeting in CREST 17th March 2006. Online: https://ec.europa.eu/invest-in-research/pdf/download_en/280206_handbook.pdf

Gaeddler, Fabian - Bronwyn H Hall - Dietmar Harhoff: 'Should there be Lower Taxes on Patent Income'. IFD Working Paper W18/19, Institute for fiscal studies, July 2018. Online: www.ifs.org.uk/uploads/publications/wps/WP201819.pdf

Európai Tükör 2020/4. 
Griffith, Rachel - Helen Miller - Martin O'Connell: 'Ownership of intellectual property and corporate taxation'. Journal of Public Economics 112 (2014), 12-23. Online: https://doi.org/10.1016/j.jpubeco.2014.01.009

Guenther, Gary: Patent Boxes: A Primer. Congressional Research Service Report, 2017. Online: https://fas.org/sgp/crs/misc/R44829.pdf

Grubert, Harry: 'Intangible income, intercompany transactions, income shifting, and the choice of location'. National Tax Journal 56, no 1 (2003), 221-242. Online: www. ntanet.org/NTJ/56/1/ntj-v56n01p221-42-intangible-income-intercompany-transactions.pdf, Online: https://doi.org/10.17310/ntj.2003.1S.05

Grubert, Harry - Joel Slemrod: 'The effect of taxes on investment and income shifting to Puerto Rico'. Review of Economics and Statistics 80, no 3 (1998), 365-373. Online: https://doi.org/10.1162/003465398557609

'Implied tax subsidy rates on $\mathrm{R} \& \mathrm{D}$ expenditures, $\mathrm{R} \& \mathrm{D}$ tax incentive indicators'. The OECD R\&D Statistics database. Online: https://stats.oecd.org/

Karkinsky, Tom - Nadine Riedel: 'Corporate taxation and the choice of patent location within multinational firms'. Journal of International Economics 88, no 1 (2012), 176-185. Online: https://doi.org/10.1016/j.jinteco.2012.04.002

'Main features of R\&D tax incentives provisions in selected OECD and non OECD countries.' OECD, 2020. Online: https://stats.oecd.org/

'Main Science and Technology Indicators'. The OECD MSTI database. Online: https:// stats.oecd.org/

McFetridge, Donald G - Jacek P Warda: Canadian R\&D Tax Incentives: Their Adequacy and Impact. Toronto, Canadian Tax Foundation, 1983.

OECD Review of National R\&D Tax Incentives and Estimates of R\&D Tax Subsidy Rates. TAX4INNO Project 674888, Deliverable 3.5: Summary report on tax subsidy rates - core countries (Year 3), Version 26 February 2019. OECD, Paris. Online: www.oecd.org/sti/ rd-tax-stats-design-subsidy.pdf

OECD R\&D tax incentives database, 2020 edition. Online: www.oecd.org/sti/rd-tax -stats-database.pdf

$R \& D$ tax incentives: design and evidence. Working Party on Innovation and Technology Policy Document, DSTI/IND/STP, OECD, Paris, June 14, 2016. Online: https://one. oecd.org/document/DSTI/IND/STP(2016)1/REV1/en/pdf

Supporting Investment in Knowledge Capital, Growth and Innovation. OECD, 2013. Online: https://doi.org/10.1787/9789264193307-sum-en

Stöwhase, Sven: 'Profit shifting opportunities, multinationals, and the determinants of FDI'. Discussion Paper No. 2002-11, Ludwig-Maximilians Universität München, Munich, December 2, 2002. Online: https://epub.ub.uni-muenchen.de/29/1/0211_ stoewhase.pdf DOI: https://doi.org/10.5282/ubm/epub.29

The Innovation Imperative: Contributing to Productivity, Growth and Well-Being. OECD, October 14, 2015. Online: https://doi.org/10.1787/9789264239814-en

Warda, Jacek P: 'Measuring the value of R\&D Tax Treatment in OECD Countries'. STI Review: Special Issue on New Science and Technology Indicators. OECD Publishing 27 (2001), 185-211. Online: www.oecd.org/sti/37124998.pdf 
Wilson, Daniel J: 'Beggar thy neighbor? The in-state, out-of-state, and aggregate effects of R\&D tax credits'. The Review of Economics and Statistics 91, no 2 (2009), 431-436. Online: https://doi.org/10.1162/rest.91.2.431

'World Indicators of Skills for Employment (WISE) Dataset'. The OECD R\&D Statistics database. Online: https://stats.oecd.org/Index.aspx 